\title{
Lessons from the Terra Preta de Índios of the Amazon Region for the Utilisation of Charcoal for Soil Amendment
}

\author{
Etelvino H. Novotny, ${ }^{a}$ Michael H. B. Hayes, ${ }^{b}$ Beáta E. Madari, ${ }^{c}$ Tito J. Bonagamba, ${ }^{d}$ Eduardo R. \\ deAzevedo, ${ }^{d}$ André A. de Souza, ${ }^{d}$ Guixue Song, ${ }^{e}$ Christiane M. Nogueira ${ }^{f}$ and Antonio S. Mangrich ${ }^{*, g}$ \\ ${ }^{a}$ Embrapa Solos, Rua Jardim Botânico 1024, 22460-000 Rio de Janeiro-RJ, Brazil \\ ${ }^{b}$ Chemical and Environmental Sciences, University of Limerick, Ireland \\ ${ }^{c}$ Embrapa Arroz e Feijão, CP 179, 75375-000 Santo Antônio de Goiás-GO, Brazil \\ ${ }^{d}$ Instituto de Física de São Carlos, Universidade de São Paulo, CP 369, 13560-970 São Carlos-SP, Brazil \\ ${ }^{e}$ Department of Civil, Environmental, and Sustainable Engineering, Ira A. Fulton School of Engineering, Arizona State \\ University, PO Box 875306, Tempe, AZ 85287-5306 USA

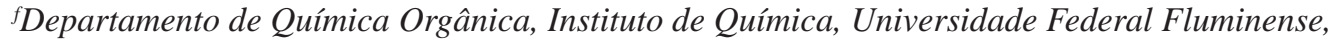 \\ 24020-150 Niterói-RJ, Brazil \\ ${ }^{8}$ Departamento de Química, Centro Politécnico, Universidade Federal do Paraná, CP 19081, \\ 81531-990 Curitiba-PR, Brazil
}

\begin{abstract}
Neste trabalho faz-se a divulgação do potencial de carvões e resíduos orgânicos parcialmente carbonizados visando obter materiais que mimetizam a matéria orgânica do solo das Terras Pretas de Índio da Amazônia, e que sirvam como condicionadores de solo e sequiestrem carbono de forma recalcitrante e reativa. Pesquisas desenvolvidas por grupos brasileiros e estrangeiros têm contribuído para o entendimento do surgimento e utilização das Terras Pretas de Índio da Amazônia. Aqui são divulgados resultados de estudos químicos no sentido do desenvolvimento do conhecimento científico e tecnológico e de inovação no aproveitamento de subprodutos orgânicos, principalmente de indústrias de biocombustíveis, carvão vegetal metalúrgico e outros, buscando imitar a excelente performance da chamada Terras Pretas de Índio da Amazônia.
\end{abstract}

The potential of charcoal and of partially combusted organic waste to mimic the soil organic matter of the Terras Pretas de Índios (Amazonian Dark Earths) from the Amazon Region is discussed. These materials serve as soil conditioners and as sequesterers of carbon in recalcitrant and in reactive forms. Studies carried out by Brazilian and by international groups have contributed to the emergence of an awareness of the compositions and of the uses of these materials. In this contribution we report on chemical studies that are leading to the development of a scientific and technological awareness, and of innovations that will have value in finding novel uses in applications to soil of chars from organic wastes such as those from the biofuel industry, and from metallurgical and various coal plant residues.

Keywords: nuclear magnetic resonance, NMR, black carbon, charcoal, C sequestration, Terra Preta de Índios

\section{Introduction}

\subsection{The Indians Black Earths (Terra Preta de Índios)}

Many soils of the Amazon Region are highly weathered, acidic, with low cation exchange capacity
(CEC), low fertility and, consequently, low crop production potential. Soil fertility is the limiting factor for the development of sustainable agriculture in the Region. The Terra Preta de Índios (TPI) soils contrast with other Amazonian soils, especially in relation to fertility and resilience.

*e-mail: mangrich@quimica.ufpr.br 


\subsection{Soil organic matter}

Environmental organic matter provides a link between the biosphere, geosphere, hydrosphere and atmosphere. It is, therefore, crucial for the sustainability of the ecosystem. Estimates of the total mass of organic carbon in soil vary from $1.22 \times 10^{18} \mathrm{~g}$ to $2.46 \times 10^{18} \mathrm{~g},{ }^{1}$ and that far exceeds the carbon reserves above the surface of the earth. ${ }^{2}$ The reserves of carbon in fossil fuels (natural gas, oil, coal etc.) are estimated at $5 \times 10^{18} \mathrm{~g}$ of carbon. However, that reservoir of carbon is relatively inactive until combusted. In contrast, the reservoir of soil organic carbon interacts with the atmosphere and therefore affects its content of $\mathrm{CO}_{2}$. Because the content of carbon stored in soil is 3 to 4 times greater than the amount in biomass, actions that increase the stock of carbon in the soil can be considered to provide more effective conservation of carbon than changes in biomass contents. In addition, an increase in soil carbon content enhances soil fertility, especially in tropical conditions, and with that the content of plant biomass that the soil is able to support.

The soil carbon stock is in a dynamic equilibrium state in which there is a continuous process of deposition $\left(5.67 \times 10^{16} \mathrm{~g}\right.$ of carbon per year), in the form of plant and animal residues, and of natural decomposition of soil organic matter (emission of $5.5 \times 10^{16} \mathrm{~g}$ of carbon per year). The emissions restore part of the atmospheric $\mathrm{CO}_{2}$ fixed by photosynthesis. The flows are not identical, as would be predictable in a system in dynamic equilibrium, due to the input of fossil carbon to the cycle, through the burning of fossil fuels that emit annually $5 \times 10^{15} \mathrm{~g}$ of carbon. These emissions are an order of magnitude smaller than those resulting from the natural decomposition of soil organic matter.

In view of the difference in magnitude of stocks and flows, the importance of soil organic matter in global carbon strategies is evident. It is obvious that its impact and contributions must be taken into account in the planning of strategies aimed at mitigating anthropogenic emissions. ${ }^{3}$

Organic matter plays a major role in soil quality. This arises from the influence that the quantity and quality of organic matter has on the physical, chemical and biological properties of soil. These properties influence the stabilities of soil aggregates, decrease plasticity, increase waterholding capacity, increase $\mathrm{CEC}$, and govern the microbial respiration of certain species. ${ }^{4}$ Additionally, organic matter is usually the main site for the sorption in soil of pesticides and of trace metals, whether as micronutrients or as toxicants. ${ }^{5}$ These influences are especially important in tropical soils. Highly weathered soils of tropical and subtropical regions are naturally acid and with a mineral fraction composed mainly of low activity clays. ${ }^{6}$

\subsection{The superiority of the TPI}

TPI are soils that have an archeo-anthropogenic horizon. This is a surface horizon of variable depth, enriched in organic matter and containing pieces of ceramic (Figure 1) as well as other evidence of human activity. ${ }^{7}$
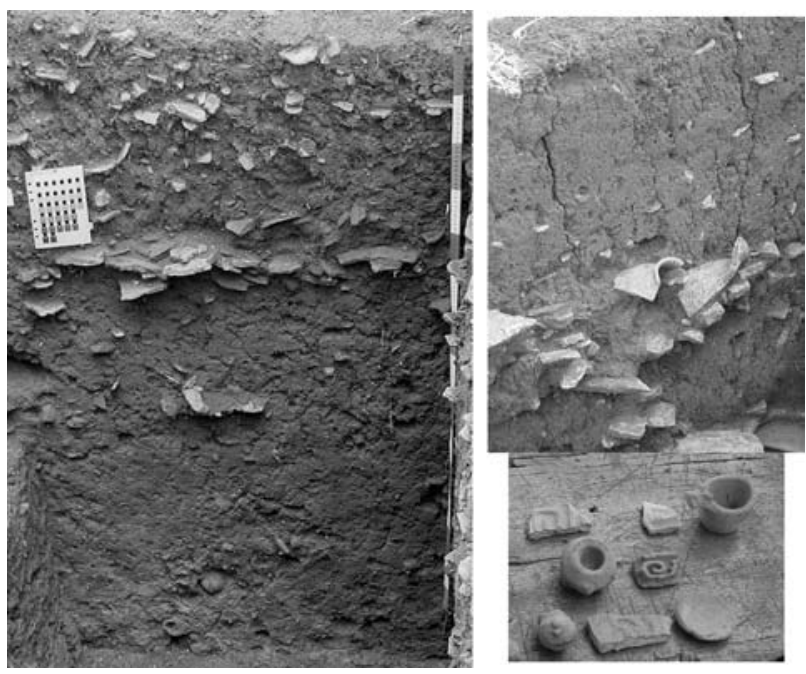

Figure 1. Photographs of TPI profiles and of ceramic artifacts found in these soils.

TPI soils occur in small patches, many of which do not exceed 2 ha, although areas of up to 350 ha have been reported. ${ }^{7}$ Currently it is accepted that the TPI are of pre-Columbian origin, the result of activities of indigenous peoples, although it is unclear whether it is a result of an intentional process of improving the soil, or the consequence of agricultural and domestic activities of these peoples. Human activity in the pre-Columbian past has resulted in the accumulation of plant and animal residues, as well as large quantities of ash, charcoal, and various chemical elements, such as $\mathrm{P}, \mathrm{Mg}, \mathrm{Zn}, \mathrm{Cu}, \mathrm{Ca}, \mathrm{Sr}$ and $\mathrm{Ba}$, representing the geochemical signature of human occupation. ${ }^{8}$ These accumulations probably contributed decisively to the formation of fertile soils, with higher $\mathrm{pH}$, $\mathrm{Ca}$ and $\mathrm{Mg}, \mathrm{P}, \mathrm{CEC}$ and base saturation, compared with the adjacent non anthropogenic soils (Table 1).

Table 1. Chemical attributes of soils of the Amazon Region

\begin{tabular}{|c|c|c|c|c|c|}
\hline \multirow[t]{2}{*}{ Soils } & \multirow[t]{2}{*}{$\mathrm{pH}$} & $\mathrm{Ca}+\mathrm{Mg}^{\mathrm{a}} /$ & CEC / & \multirow{2}{*}{$\begin{array}{c}\mathrm{P}^{\mathrm{b}} / \\
\left(\mathrm{mg} \mathrm{kg}^{-1}\right)\end{array}$} & \multirow{2}{*}{$\begin{array}{c}\text { Base } \\
\text { Saturation }^{\mathrm{c}} / \%\end{array}$} \\
\hline & & \multicolumn{2}{|c|}{$\left(\mathrm{cmol}_{\mathrm{c}} \mathrm{kg}^{-1}\right)$} & & \\
\hline Control & 4.4 & 1.3 & 9.5 & 5 & 21 \\
\hline TPI & 5.4 & 6.8 & 17.3 & 300 & 55 \\
\hline
\end{tabular}

${ }^{\mathrm{a}}$ exchangeable; ${ }^{\mathrm{b}}$ mehlich; ${ }^{\mathrm{c}}$ base saturation $=(\mathrm{Ca}+\mathrm{Mg}+\mathrm{K}) / \mathrm{CEC}$.

The high fertility of the TPI, and in particular its resilience (the capacity of these soils to maintain high 
fertility in spite of its intensive and degradative use), is attributed to the high levels of soil organic matter and to the physical and chemical properties of this organic matter. These soils have a carbon content of up to $150 \mathrm{~g} \mathrm{~kg}^{-1}$ of soil, compared with $20-30 \mathrm{~g} \mathrm{~kg}^{-1}$ in adjacent soils. ${ }^{1,9}$ Additionally, the enriched layer of carbon can be up to $200 \mathrm{~cm}$ deep, with an average depth of the order of $40-50 \mathrm{~cm}$, whereas the carbon in the adjacent soils is limited to the top $10-20 \mathrm{~cm}$. Thus, the stock of carbon in the TPI may be an order of magnitude higher. This additional carbon is mainly in the form of pyrogenic carbon, ${ }^{9}$ and can be up to six times more stable than that in adjacent soil.

This pyrogenic carbon (black carbon) is derived from the partial carbonisation (pyrolysis) mainly of ligno-cellulosic materials and is composed of condensed polyaromatic units, deficient in hydrogen and with different sizes and organisational levels. ${ }^{10}$ This material is highly resistant to thermal-, chemical- and photo-oxidation, ${ }^{11}$ and due to its recalcitrance, its incorporation into the soil is an important and efficient mechanism of carbon sequestration. ${ }^{9,12}$ However, the partial oxidation of the aromatic peripheral units produces carboxylic groups directly linked to the recalcitrant aromatic structures. ${ }^{13}$ The carboxylic groups of these materials contribute to the elevated total acidity (CEC) and consequently to the high fertility of the soil. Additionally, its recalcitrant aromatic structure ensures the sustainability and resilience of this fertility. ${ }^{14}$

In Brazil, pyrogenic carbon is not restricted to TPI, and its occurrence is not always anthropogenic. The occurrence of pyrogenic carbon is common in soils where there are historical reports of the burning of vegetation, natural or anthropic, and it is an important component of the organic matter of the Brazilian Savannas ("Cerrado"), ${ }^{15}$ and in the black soils found in high altitude rocky complexes. ${ }^{6}$ Similar to the TPI, the organic matter of these soils presents high recalcitrance and CEC values. Due to its high stability and reactivity, the weathered pyrogenic carbon is of great importance for tropical soils subject to weather conditions that favour the mineralisation of organic matter, and where the clay fraction has low CEC values (Table 2).

Table 2. Typical values for the CEC of clay minerals and organic colloids found in soils of temperate and tropical climates

\begin{tabular}{llc}
\hline & Soil Constituent & CEC / $\left(\mathrm{cmol}_{\mathrm{c}} \mathrm{kg}^{-1}\right)$ \\
\hline Temperate climate & Montmorilonite & $80-120$ \\
& Vermiculite & $120-150$ \\
Tropical climate & Kaolinite & $3-15$ \\
& Sesquioxides & $2-4$ \\
Organic Fraction & Soil organic matter (SOM) & $100-300$ \\
& Humic fraction (2/3 of the & $400-800$ \\
& SOM) & \\
\hline
\end{tabular}

Pyrogenic carbon is not only found in tropical soils. It is estimated that pyrogenic carbon represents 1 to $6 \%$ of the total world soil organic carbon, but can reach $18 \%$ of the total soil organic carbon in native grasslands in the U.S.; $35 \%$ in some agricultural soils of that country; up to $30 \%$ in Australian soils; up to $45 \%$ in German Chernozems; and $65 \%$ in Canadian Chernozems. ${ }^{16}$ Several of these soils are very fertile.

\section{Structural Characteristics of the TPI Or- ganic Matter: Model Definition}

Currently it is understood that the production systems of ancient indigenous populations can provide insights that serve as the basis for the development of sustainable agricultural management, and the TPI provides an excellent model of sustainable agriculture. That model is especially useful in tropical ecosystems that sequester carbon.

The contribution of pyrogenic carbon to soil fertility and to its sustainability is attributed to its composition and chemical structure. In order to check this hypothesis, humic acids extracted by conventional methods ${ }^{13}$ from 22 Amazonian soils (seven TPI under forest, eleven cultivated TPI and four adjacent non-anthropogenic control soils under forest) were analysed by ${ }^{13} \mathrm{C}$ Nuclear Magnetic Resonance spectroscopy $\left({ }^{13} \mathrm{C} \mathrm{NMR}\right)$ as described by Novotny et $a l .{ }^{17}$ Although humic acids are only a fraction of soil organic matter, accounting for 20 to $45 \%$ of the total soil organic matter in the samples studied, ${ }^{18}$ their contribution to soil chemistry and fertility is well-documented in the literature. ${ }^{4}$

The results of this analysis showed that the humic acids of the TPI are rich in condensed aromatic structures, as shown by recoupled dipolar dephasing experiments, and functionalised with carboxylic groups linked directly to these recalcitrant aromatic structures (Figure 2a), as evidenced by the chemical shift decrease from around $175 \mathrm{ppm}$ to around $168 \mathrm{ppm}$. In contrast, the humic acids of adjacent soils (Figure 2b) have a higher content of partially altered labile compounds, such as carbohydrates, amino acids and lignins..$^{13,17}$

It is probable that the extraction procedure resulted in a selective extraction of this functionalised charcoal, because the unaltered material is essentially hydrophobic, but, as it will be shown, these structures also have an important contribution to the exceptional fertility of the TPI. Thus knowledge of their structures and characteristics is very important in order to define a model for soil amendment.

The contents of these recalcitrant and reactive structures correlate with the thermal stability of those humic acids. Also, elemental composition data indicate a high degree of condensation of aromatic rings (low $\mathrm{H} / \mathrm{C}$ atomic ratio). 

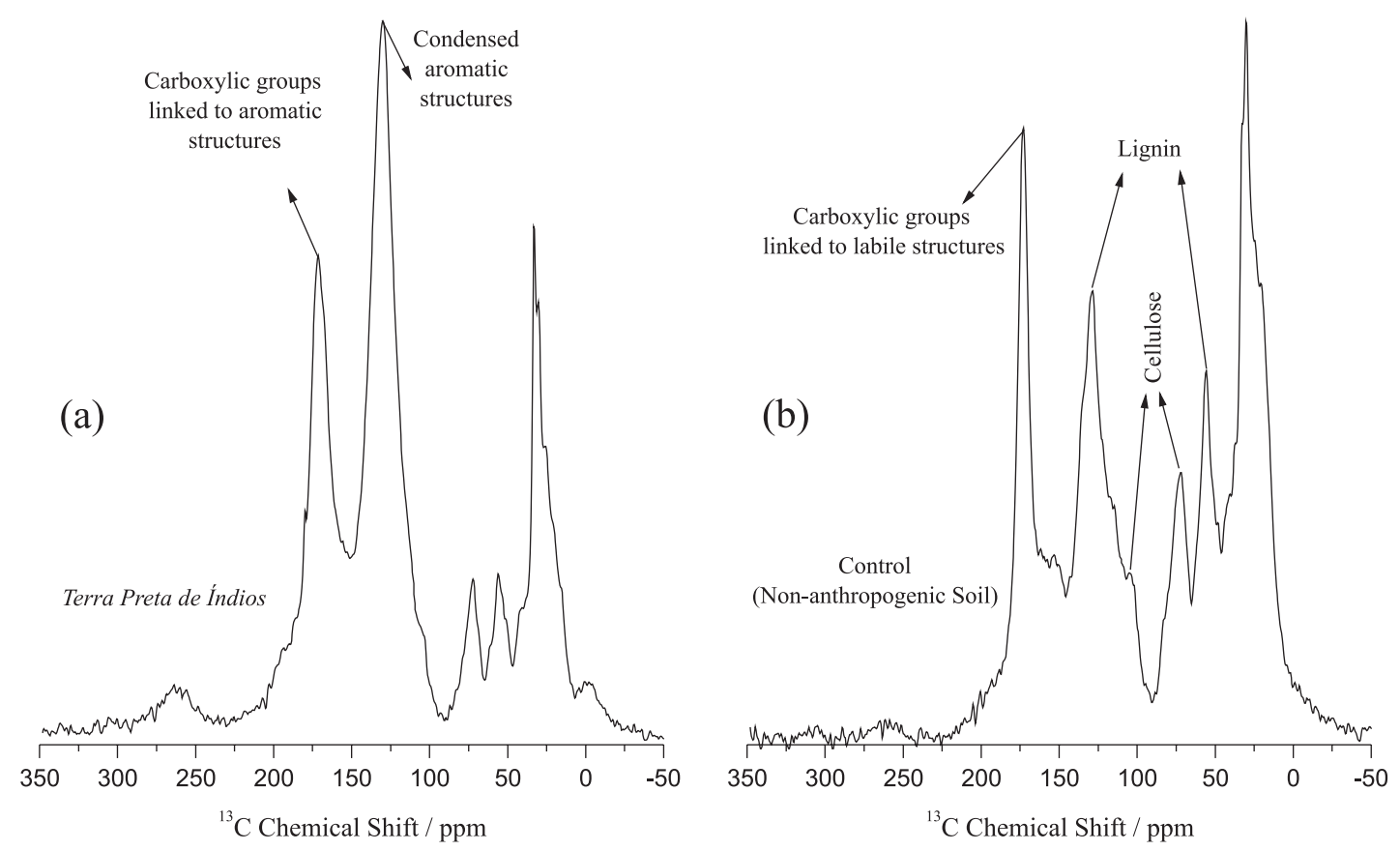

Figure 2. ${ }^{13} \mathrm{C}-\mathrm{NMR}$ spectra of humic acids from Amazon region soils. (a) TPI; (b) Non-anthropogenic soil. ${ }^{13}$

The data confirm, by independent methods, that the humic acids of TPI are characterised by high thermal and structural stability. In addition, the reactive oxygenated groups, such as carboxyl and phenolic, are recalcitrant, whereas the oxygenated groups in adjacent soils are associated mainly with labile or poorly reactive structures, such as carbohydrates, peptides and lignin. This hypothesis is supported by the relative concentration of carboxylated aromatic structures observed when these soils are cultivated (see below), because of the selective decomposition of the labile structures. The long term persistence of these structures in the TPI environment, from 500 to 3,000 years, is proven by radiocarbon dating. ${ }^{19}$

To aid in the analyses of the results, the multivariate curve resolution (MCR) procedure was carried out using the software 'The Unscrambler ${ }^{\circledR}$ v9.7' (CAMO Software AS). The basic goals of MCR are: the determination of the number of components co-existing in the chemical system; the extraction of the pure spectra of the components (qualitative analysis); and the extraction of the concentration profiles of the components (quantitative analysis).

This analysis is preceded by principal component analysis (PCA) to estimate the number of components in the mixture. After this, the rotation of the $\mathrm{PC}$ is calculated without orthonormality constrains (in this way it will have infinite solutions). To solve this, new constrains are adopted (e.g. non-negative concentrations and non-negative spectra). In this way, when the goals of MCR are achieved, it is possible to unravel the "true" underlying sources of data variation, and then the results with physical meaning are easily interpretable.

The results of this analysis indicate that the humic acids of the 22 Amazonian soils can be modelled by means of a two component mixture (Figure 3a): one of ordinary tropical humic acids with carbohydrates, peptides and lignin debris (labile components), and one with a polycondensed and carboxylated aromatic structure (oxidised charcoal). The carboxylic region in the spectrum of the labile component is mainly from aliphatic carboxyl and amide groups $(173 \mathrm{ppm})$ whereas, when this group is linked directly to the aromatic structures, its signal shits to $168 \mathrm{ppm}$. The contributions of these components vary among the soils. The major contribution of the oxidised charcoal was seen in the cultivated TPI (Figure 3b). That indicates that cultivation promotes the selective degradation of the labile components. Based on the well-known resilience of these TPI soils, the persistence of oxidised charcoal after several centuries, or even millennia, despite recent cultivation, supports the conclusion that this component makes an important contribution to the fertility and resilience of these soils. It also explains the efficient $\mathrm{C}$ sequestration by these soils. In the cases of the control soils, the humic acids have important contributions from normally labile acid groups (aliphatic carboxyl and amide), and these compounds have an important contribution to the fertility of the soils. However, when the soils are deforested and cultivated, the organic matter is quickly mineralised and the soil loses fertility. This is a well-known phenomenon in tropical 

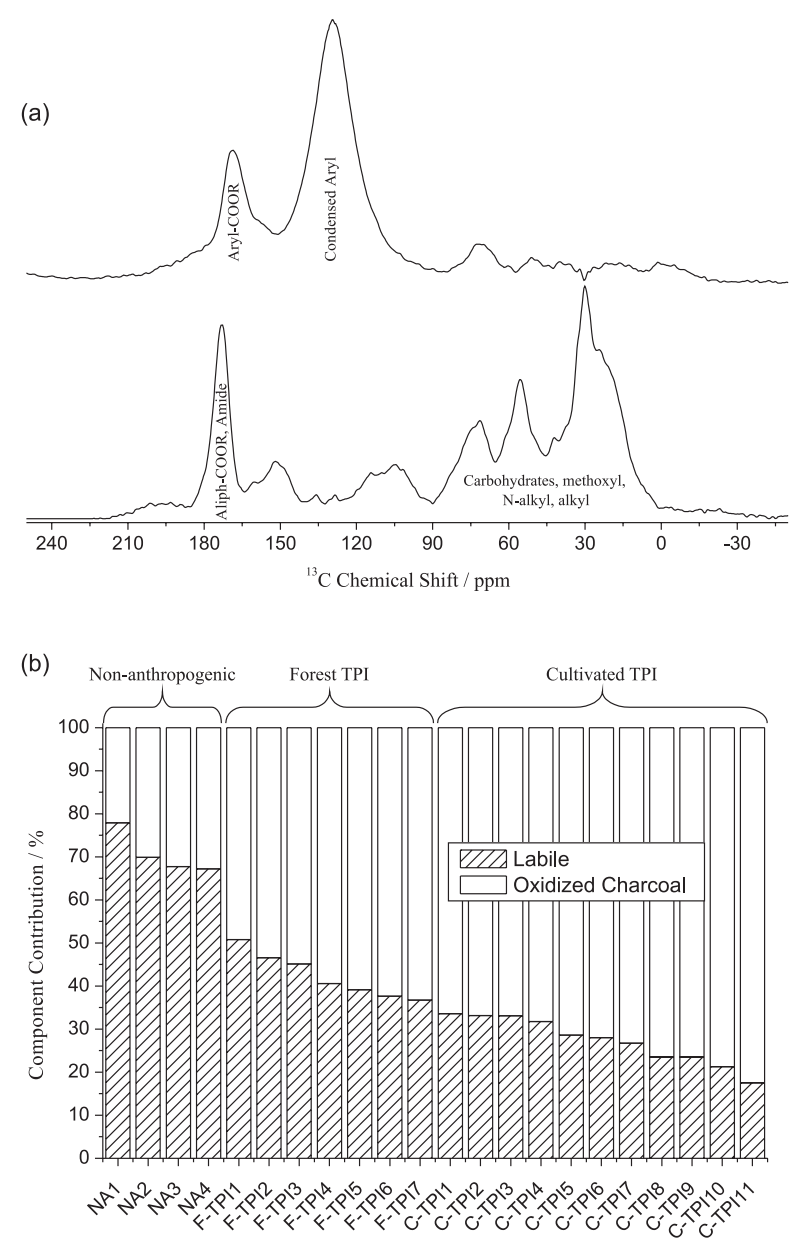

Figure 3. Results of multivariate curve resolution (MCR) analysis. (a) Estimated spectra; (b) Estimated concentrations. NA: Non-anthropogenic control soils under forest; F-TPI: TPI under forest; C-TPI: Cultivated TPI.

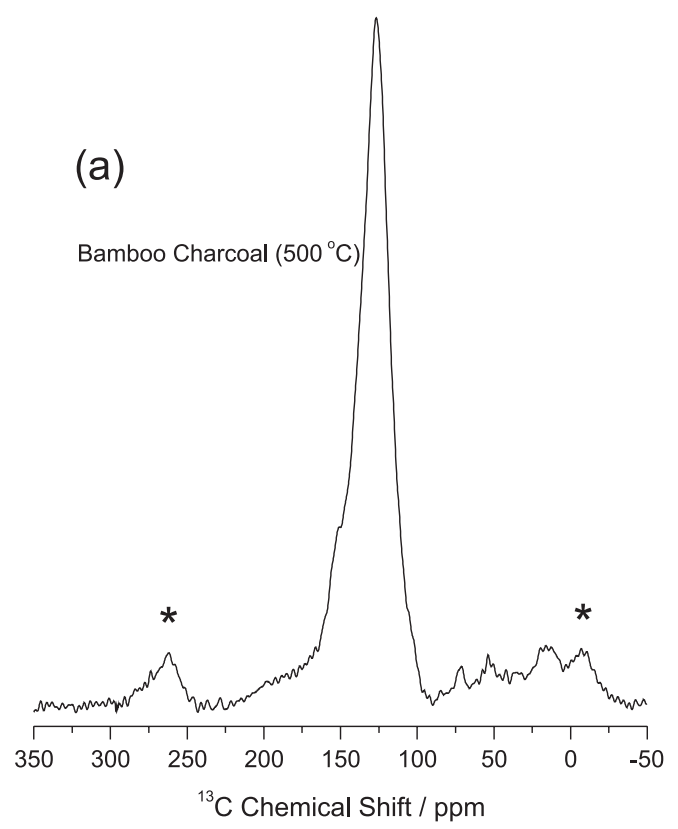

soils, and a common example for this is the rapid loss of the fertility of soils after slash and burn and cultivation, and this results in the necessity of frequent long-fallow periods and shifting cultivations. ${ }^{20}$

In other words, the TPI provide a system that sequesters carbon and also improves soil properties, increasing their fertility, sustainability, and biomass supporting capacity. These characteristics could be explained by the high content of oxidised charcoal in these soils.

\subsection{Using the organic matter of TPI as a model}

Knowledge of the structures and properties of the TPI allows considerations of materials and techniques that will expeditiously mimic their desirable characteristics. Charcoal has the condensed aromatic structures that ensure their recalcitrance in the soil, and hence is an efficient material for carbon sequestration (half-life ranging from decades to millennia), ${ }^{21,22}$ but it does not provide carboxylic groups (Figure 4a) that are important for its reactivity and its contribution to soil CEC. After application to the soil, chemical and biological alterations will generate these acid groups; however, this may take decades. Functionalisation of the aryl backbone in typical charcoal structures is possible by chemical oxidation (Figure 4b), ${ }^{23}$ that generates recalcitrant and reactive products, similar to the oxidised charcoal found in TPI. ${ }^{13,14,17}$

Additionally, applications of charcoal to the soil provides other benefits such as: increases in productivity (from 0 to $300 \%$ ); decreases the methane and nitrous

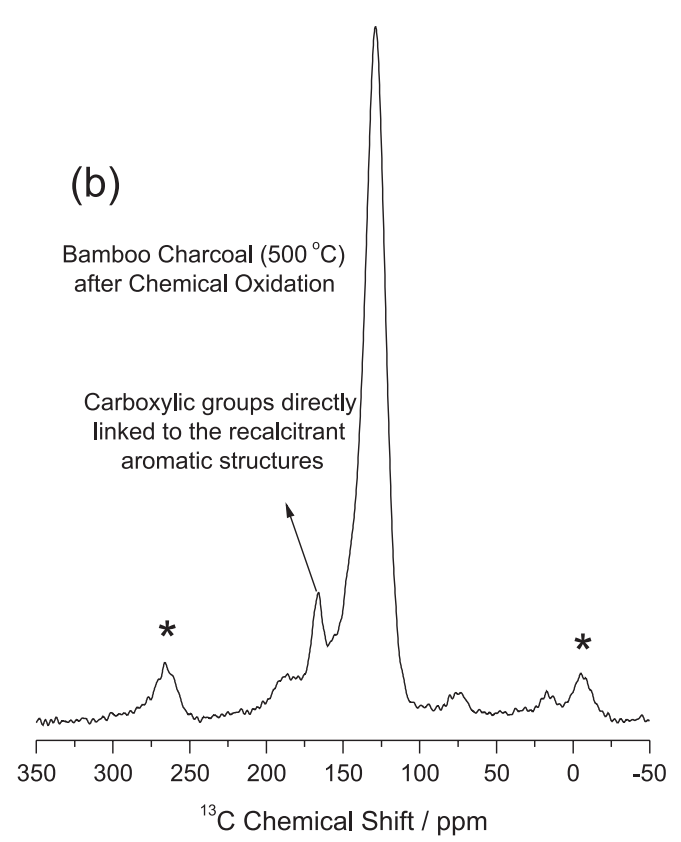

Figure 4. ${ }^{13} \mathrm{C}$-NMR spectra of charcoal (a) and chemical oxidation products of Bamboo charcoal (b). 
oxide emissions (estimated at up to $50 \%$ ), decreases in the need for fertiliser (estimated at 10\%); and decreases in the leaching of nutrients. ${ }^{24}$ Besides the economic benefits, the environmental benefits should also be taken into account, ${ }^{22}$ especially with regard to global climate change (C sequestration) and, in this context, the environmental benefits will be enhanced by reducing the emissions of other greenhouse effect gases $\left(\mathrm{CH}_{4}, \mathrm{~N}_{2} \mathrm{O}\right.$ and $\left.\mathrm{NO}_{x}\right)$, and by greater energy efficiencies of agriculture due to increased productivity, reduced use of fertilisers, and less loss of nutrients.

\section{Acknowledgments}

The authors are grateful to the Science Foundation Ireland (SFI), CNPq, and FINEP-PADCT for financial support.

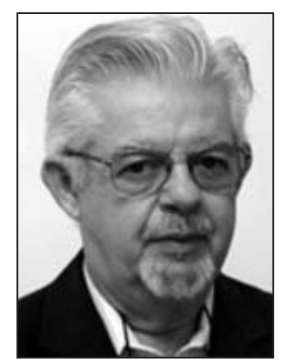

Antonio S. Mangrich graduated in Chemistry from the State University of Rio de Janeiro (1969), and received his doctorate in Chemistry in 1983 from the Institute of Chemistry of the Federal University of Rio de Janeiro, under the supervision of Prof. Ricardo B. de Alencastro and Prof. Ney V. Vugman, working with soil organic matter interaction with paramagnetic metal ions using electron paramagnetic resonance (EPR) as the principal technique of analysis. Currently, he is a full professor at the Department of Chemistry, Federal University of Parana. He is a former president of the Brazilian Chemical Society and an invited member of the Council for the Social and Economic Development from the Brazilian Presidency of the Republic. His interests are focused in soil chemistry and developing of new and innovative fertilizers for agriculture in tropical soils.

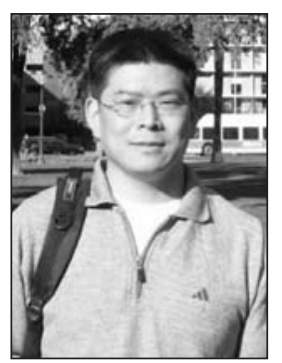

Guixue Song received his M.Sc. in Environmental Chemistry from the Eco-Environmental Research Center, Chinese Academy of Sciences in 1996 and his PhD in Soil Organic Chemistry in 2008 from University of Limerick, Ireland, under the supervision of Prof. M. H. Hayes, working on the isolation and characterization of humic substances (including Terra Preta soils) and carbon sequestration in soils. Currently, he is a post-doctoral fellow at the Department of Civil,
Environmental and Sustainable Engineering, Arizona State University, USA, under the supervision of Prof P. Westerhoff. His interests are in the fields of natural organic matters and biochar applications in soil and industry.

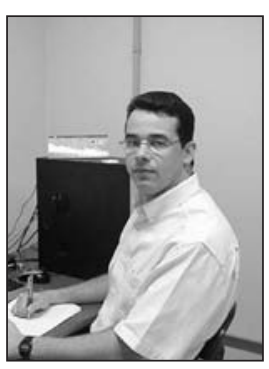

Eduardo Ribeiro de Azevedo obtained his doctorate in Physics from the Physics Institute of São Carlos, University of São Paulo, in 2001. In 2003, he obtained the position of Assistant Professor of Physics at the University of São Paulo. His research activities are centered on the development of NMR methods and their application in structural characterization and the dynamics of organic matter and materials, as well as quantum information processing.

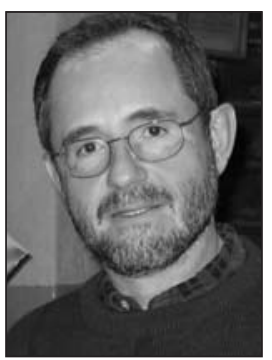

Tito José Bonagamba received his doctorate in Physics in 1991 from the Physics Institute of São Carlos, University of São Paulo. Teaching at the Physics Institute since 1988, he is currently a Full Professor. He spent two and a half years at the Department of Polymer Science and Engineering (University of Massachusetts), and the Ames Laboratory and Department of Chemistry (Iowa State University) as a visiting scientist. He was also several times a visiting professor in Germany (Institute of Physics, Martin Luther Halle-Wittenberg University - Halle) and France (Institut de Chimie Moléculaire et des Matériaux d'Orsay - Laboratoire de RMN en Millie Orienté - Université Paris-Sud 11 Orsay). His research interests include the development and utilization of multidimensional solid-state NMR methods and their applications to study materials, NMR instrumentation, and quantum computation.

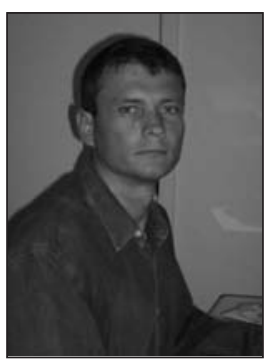

Etelvino Henrique Novotny obtained his MSc in Soil Chemistry from the Federal University of Parana and the Universität für Bodenkultur Wien, Austria in 1997 and his doctorate in Physical Chemistry from the Chemistry Institute of São Carlos, University of São Paulo, in 2002. He was a post-doctoral fellow at the Physics Institute of São Carlos, University of São Paulo (2005-2008), working with development of NMR methods and their application in the characterization of 
environmental organic matter and a post-doctoral fellow at the University of Limerick, Ireland (2005-2009), working with the isolation and characterization of humic substances, including Amazonian "Terra Preta de Índios" soils. In 2001, he obtained the position of Researcher at Brazilian Agricultural Research Corporation. His interests are in the fields of environmental organic matters and biochar functionalization and its applications in soil.

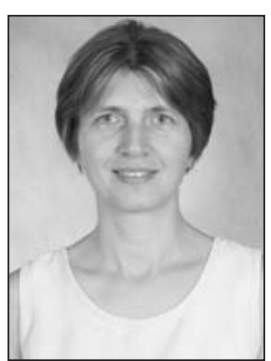

Beáta Emöke Madari graduated in Agronomy at Gödöllö University of Agricultural Sciences, Hungary (1994), where she also concluded a PhD ("sandwich" PhD at Agronomy Department at Purdue University, U.S.A.) in Soil Science and Plant Nutrition (1999) with emphasis in soil organic matter (SOM) interactions and characterization. She was a research fellow (2000-2002) and research scientist (2002-2005) at the Brazilian Agricultural Research Corporation's National Soil Research Center (Embrapa Soils). Presently, she is a research scientist at Embrapa Rice and Beans (since 2005) and professor at in Post-Graduate Program in Agronomy at the Federal University of Goiás (since 2008). Assistant editor of Brazilian Journal of Soil Science (RBCS, ISSN 0100-0683, since 2006). Her interests are in soil management systems, soil fertility, soil conservation, SOM fractionation and characterization, infrared spectroscopy and agronomic use of biochar.

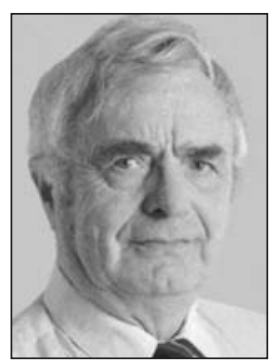

Michael H.B. Hayes reveived his MS from Cornell (Ithaca, NY) and his PhD from the Ohio State University. Currently he is a professor of Chemical and Environmental Sciences, University of Limerick, Ireland; a Committee Member of the International Biochar Initiative; Member of the Royal Irish Academy; Honorary Member of the International Humic Substances Society, of the Soil Science Society of America, and of the American Society of Agronomy. His research interests include: the chemistry of soil organic matter; interactions between inorganic and organic colloids of the soil environment; biorefining, involving pathways of transformations of lignocellulosic biomass to furfural, hydroxymethyl furfural, formic acid, and biorefinery residuals, pyrolysis of the residuals to syngas, bio-oil, and biochar and the influences of biochar and of bio-oil on plant growth and on soil carbon sequestration.

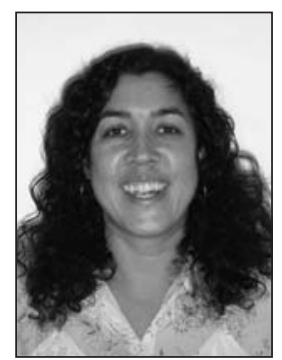

Christiane Mapheu Nogueira graduated in Industrial Chemistry in 1994 and received her Master's Degree in Organic Chemistry in 1996 from Fluminense Federal University. Between 1996 and 2000 she acted as Visiting Researcher at FIOCRUZ, working with synthetic drugs. She received her $P h D$ in Chemistry from the Federal University of São Carlos in 2005. Nowadays she is a postdoctoral fellow in the Pos-Graduate Program in Organic Chemistry of the Fluminense. Federal University. Her research interests are NMR spectroscopy and organic synthesis, particularly in carbohydrates and heterocyclics.

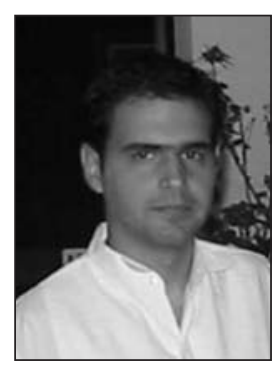

André A. de Souza graduated in Physical Engineering from the Federal University of São Carlos in 2004. He concluded his Master's degree in Materials Engineering with emphasis in development, characterization and application of materials in 2007, at the Physcis Institute of São Carlos, University of São Paulo. Currently, he is a PhD student in the same area at the same Institute. His research interests are in the characterization of complex materials with advanced NMR methods.

\section{References}

1. Sombroek, W. G.; Nachtergaele, F. O.; Hebel, A.; Ambio 1993, 22, 417 .

2. Batjes, N. H.; Eur. J. Soil Sci. 1996, 47, 151.

3. Schnitzer, M.; Soil Sci. 1991, 151, 41; Piccolo, A.; Mbagwu, J. S. C.; Soil Sci. Soc. Am. J. 1994, 58, 950; Borin, M.; Menini, C.; Sartori, L.; Soil Tillage Res. 1997, 40, 209; Reicosky, D. C.; Dugas, W. A.; Torbert, H. A.; Soil Tillage Res. 1997, 41, 105; Swift, R. S.; Soil Sci. 2001, 166, 858; Song, G.; Novotny, E. H.; Simpson, A. J.; Clapp, C. E.; Hayes, M. H. B.; Eur. J. Soil Sci. 2008, 59, 505.

4. Stevenson, F. J.; Humus Chemistry: Genesis, Composition, Reactions, $2^{\text {nd }}$ ed.; John Wiley: New York, 1994; Preston, C. M.; Soil Sci. 1996, 161, 144; Lovley, D. R.; Nat. Rev. Microbiol. 2006, 4, 497.

5. Senesi, N.; LaCava, P.; Brunetti, G.; Fresenius Environ. Bull. 1996, 5, 580; Lair, G. J.; Gerzabek, M. H.; Haberhauer, G.; Jakusch, M.; Kirchmann, H.; J. Plant Nutr. Soil Sci. 2006, 169, 60. 
6. Benites, V. D.; Mendonca, E. D.; Schaefer, C.; Novotny, E. H.; Reis, E. L.; Ker, J. C.; Geoderma 2005, 127, 104.

7. Woods, W. I.; Denevan, W. M. In Amazonian Dark Earths: Wim Sombroek's Vision; Woods, W. I.; Teixeira, W. G.; Lehmann, J.; Steiner, C.; WinklerPrins, A.; Rebellato, L., eds.; Springer Science: Heidelberg, 2009, ch. 1.

8. da Costa, M. L.; Kern, D. C.; J. Geochem. Explor. 1999, 66, 369.

9. Glaser, B.; Haumaier, L.; Guggenberger, G.; Zech, W.; Naturwissenschaften 2001, 88, 37.

10. Kramer, R. W.; Kujawinski, E. B.; Hatcher, P. G.; Environ. Sci. Technol. 2004, 38, 3387.

11. Skjemstad, J. O.; Clarke, P.; Taylor, J. A.; Oades, J. M.; McClure, S. G.; Aust. J. Soil Res. 1996, 34, 251.

12. Masiello, C. A.; Mar. Chem. 2004, 92, 201.

13. Novotny, E. H.; Deazevedo, E. R.; Bonagamba, T. J.; Cunha, T. J. F.; Madari, B. E.; Benites, V. D.; Hayes, M. H. B.; Environ. Sci. Technol. 2007, 41, 400.

14. Novotny, E. H.; Bonagamba, T. J.; deAzevedo, E. R.; Hayes, M. H. B. In Amazonian Dark Earths: Wim Sombroek's Vision; Woods, W. I.; Teixeira, W. G.; Lehmann, J.; Steiner, C.; WinklerPrins, A., Rebellato, L., eds.; Springer Science: Heidelberg, 2009, ch. 21.

15. Roscoe, R.; Buurman, P.; Velthorst, E. J.; Vasconcellos, C. A.; Geoderma 2001, 104, 185.

16. Gonzalez-Perez, J. A.; Gonzalez-Vila, F. J.; Almendros, G.; Knicker, H.; Environ. Int. 2004, 30, 855; Glaser, B.; Amelung, W.; Global Biogeochem. Cycles 2003, 17; Skjemstad, J. O.; Reicosky, D. C.; Wilts, A. R.; McGowan, J. A.; Soil Sci. Soc. Am. J. 2002, 66, 1249; Skjemstad, J. O.; Taylor, J. A.; Smernik, R. J.; Commun. Soil Sci. Plant Anal. 1999, 30, 2283; Schmidt, M. W. I.; Skjemstad, J. O.; Gehrt, E.; Kogel-Knabner, I.; Eur. J. Soil Sci. 1999, 50, 351; Ponomarenko, E. V.; Anderson, D. W.; Can. J. Soil Sci. 2001, 81, 285.

17. Novotny, E. H.; Hayes, M. H. B.; deAzevedo, E. R.; Bonagamba, T. J.; Naturwissenschaften 2006, 93, 447.
18. Cunha, T. J. F.; Madari, B. E.; Benites, V. D.; Canellas, L. P.; Novotny, E. H.; Moutta, R. O.; Trompowsky, P. M.; Santos, G. A.; Acta Amaz. 2007, 37, 91.

19. Woods, W. I.; Denevan, W. M. In Amazonian Dark Earths: Wim Sombroek's Vision; Woods, W. I.; Teixeira, W. G.; Lehmann, J.; Steiner, C.; WinklerPrins, A.; Rebellato, L., eds.; Springer Science: Heidelberg, 2009, ch. 1; Rebellato, L; Woods, W. I.; Neves, E. G. In Amazonian Dark Earths: Wim Sombroek's Vision; Woods, W. I.; Teixeira, W. G.; Lehmann, J.; Steiner, C.; WinklerPrins, A.; Rebellato, L., eds.; Springer Science: Heidelberg, 2009, ch. 2; Arroyo-Kalin, M. In Amazonian Dark Earths: Wim Sombroek's Vision; Woods, W. I.; Teixeira, W. G.; Lehmann, J.; Steiner, C.; WinklerPrins, A., Rebellato, L., eds.; Springer Science: Heidelberg, 2009, ch. 3.

20. Fraser, J.; Cardoso, T.; Junqueira, A.; Falcão, N. P. S.; Clement, C. R. In Amazonian Dark Earths: Wim Sombroek's Vision; Woods, W. I.; Teixeira, W. G.; Lehmann, J.; Steiner, C.; WinklerPrins, A.; Rebellato, L., eds.; Springer Science: Heidelberg, 2009, ch. 12.

21. Hamer, U.; Marschner, B.; Brodowski, S.; Amelung, W.; Org. Geochem. 2004, 35, 823.

22. Lehmann, J.; Nature 2007, 447, 143.

23. Trompowsky, P. M.; Benites, V. D.; Madari, B. E.; Pimenta, A. S.; Hockaday, W. C.; Hatcher, P. G.; Org. Geochem. 2005, 36, 1480; Mangrich, A. S.; Vugman, N. V.; Fuel 1990, 69, 925; Dick, D. P.; Mangrich, A. S.; Menezes, S. M. C.; Pereira, B. F.; J. Braz. Chem. Soc. 2002, 13, 177; Merce, A. L. R.; Greboge, C.; Mendes, G.; Mangrich, A. S.; J. Braz. Chem. Soc. 2005, 16, 37.

24. Gaunt, J. L.; Lehmann, J.; Abstracts of the International Agrichar Initiative 2007 Conference, Terrigal, Australia, 2007.

Received: January 29, 2009

Web Release Date: June 26, 2009

FAPESP helped in meeting the publication costs of this article. 